\title{
Study on the Origin of Shaman Culture in Olunchun
}

\author{
Lili Song \\ Heihe University \\ Heihe, China 164300 \\ Institute of Education \\ Xiamen University \\ Xiamen, China 361005
}

\author{
Kai Sun \\ Heihe University \\ Heihe, China 164300
}

\begin{abstract}
This article emphatically analyzed the value of the orogen \&matrimonial asaph from the perspective of the origin in Olunchun \&matrimonial asaph, expounded the thoughts of orogen \&matrimonial asaph, explored the Shaman \&matrimonial and the function of Olunchun \&matrimonial inheritance significance.
\end{abstract}

\section{Keywords-Olunchun; Shaman culture; source; strategy}

\section{INTRODUCTION}

Olunchun is one of the ethnic minorities in China, lives in the east of Baikal and the north of Heilongjiang Province. It is mainly distributed in the Inner Mongolia autonomous region and Heilongjiang province. Due to the relatively closed residence of the Olunchun ethnic group, Shamanism has become the spiritual pursuit and belief of the Olunchun people, which is an important basis for the survival and development of the Olunchun ethnic group. Besides, due to the factors such as geography, history and folklore, the Shaman culture of the Olunchun ethnic group is more primitive, which is of special cultural value and worldwide significance due to the attention of Chinese cultural researchers. The study of the origin of the Shaman culture of the Olunchun ethnic group not only promotes the inheritance of the culture of the Olunchun ethnic group, but also has profound significance to the development of the Shaman culture.

\section{THE ORIGIN OF THE CULTURE OF OLUNCHUN SHAMAN}

The word "Shaman" originally means "the man who danced with excitement" in Shamanism, Shaman was the master of sorcerers. Shamanism is a kind of faith, and Shamans believe that the soul is immortal, believing in the ghosts of all things, and in Shaman's grave, the world is divided into three kingdoms, heaven is the upper bound, and is the place where the gods live. The ground is human, the place where all things live. The lower bound is where the ancestral gods and demons lived. At the same time, Shaman believed that the evil fortune of the world was ruled by gods and demons, and the gods blessed the human beings, and the demons gave them the evil. Shaman prayed to the gods for welfare, avoiding disaster, and was the protection and agent of all human beings. Shamanism believes in the social forces and natural forces in the life of the gods, and to pray for the Gods, Gods, Thor, Mountain god, Tree gods and so on.

Thus it can be seen that Shamanism belongs to a kind of religious belief, which has been produced in the time of nomadic hunting and hunting. At that time, the social productivity is low, people cannot cope with the brutal force of nature, the nature of the disaster is very confused, can only hope that the gods, creating a natural worship and the worship of the gods. Moreover, the Shaman believed that the gods would bless the human beings, that the gods did not register differences, and that there was no relationship between obedience and obedience, domination and domination. At the same time, Shaman is a spiritual product and a cultural phenomenon, which originates from human life and labor, and is a spiritual product and cultural product created for survival. In addition, Shamanism is mainly responsible for the major events, the sacrificial blessing of major festivals or the elimination of disasters for the members of the Clan, which is a spontaneous, nonorganizational religion.

\section{Olunchun Ethnic Shaman CUlture BelieF}

\section{A. Nature Worship}

The natural worship in Shaman culture is mainly manifested in the worship of the world, landscape, trees, sun and moon, wind, fire, rain and so on. This kind of natural worship is the subjective understanding of nature by the people of Olunchun, and the phenomenon of anthropomorphization or divination of natural things. The worship of heaven and earth is the most important natural worship of the Shaman people, and the Olunchun people believe that heaven which gave them life and provided them with the home of life. Therefore, they believe that the god of heaven is the most important god in the world. In addition to the worship of god, the worship of mountain god is also an important worship of Shaman culture. The Olunchun people believe that the animal in the forest of the gods, the mountain god's anger and anger decides whether the hunting will be blessed. Therefore, the Olunchun people will pray to the mountain god before hunting, and pray for the smooth and safe hunting. 


\section{B. Animal Worship}

Shaman culture has a large number of animal worship, animal worship mainly includes animal spirits worship and totem worship. In the aspect of totem worship, Shamanism is regarded as a totem, and the animal has a certain mythological background. In the propagation of animal myths, the myth endows the animals with a certain divinity, which makes the people of the Olunchun people feel the awe of the animals, which in turn generates the totem worship. From the worship of animal spirits, animals are closely related to the real life, such as hunting and channeling. The worship of animal spirits is usually to pray for the avoidance of the injury or elimination of the disease by the fierce animal.

\section{Ancestor Worship}

Shaman culture has the idea that the soul is immortal. Shamanism believes that the human soul is immortal and will not disappear with the end of life. The soul tube in Shaman culture is closely related to the ancestor worship, and the worship of the soul by Shamanism is a form of remembrance of the ancestors, so the Shaman culture has the custom of ancestor worship. Shamanism believed that sacrificial ancestors could obtain the protection of ancestors, and people could eliminate disasters under the protection of their ancestors. In addition, the ancestor worship in Shaman culture not only sacrificed to their ancestors, but also sacrificed to the common ancestor of the ethnic heroes and ethnic leaders.

\section{SHAMAN}

\section{A. The Production of Shaman}

Shaman is an emissary of human and spirit communication, mainly including Clan Shaman and Wild Shaman, the Clan Shaman is mainly responsible for the family sacrificial activities, and does not help others to ward off evil spirits. Wild Shaman is mainly responsible for exorcising evil, healing, jumping and so on. There are three main ways to make Shaman, the first is to choose Shaman from the gods, the second is the succession of Shaman, and the third is the old Shaman. From the divine, the sarge demands that Shaman candidates have different characteristics from the common people, such as small mental disorders, serious illness, abnormal speech and so on. The behavior of these people was considered by the Olunchun people as a result of the gods, so that they could communicate with the gods after recovering. The succession of Shaman mainly refers to the production mode of the Clan Shaman. After the death of the Clan Shaman, the spirit is transferred to the next generation by blood, so that the next generation can become trust Shaman. The old Shaman is mainly referring to the old Shaman's choice of apprentices and strict training, so that the disciple can integrate master's style.

\section{B. The Function of Shaman}

First, Shaman has a religious function and is responsible for communicating with the gods. Shaman mainly communicates with the spirit through the form of attachment and dementor, thus helping people to cure the evil. Secondly, Shaman has the function of cohesive group. The Clan Shaman needs to conduct the sacrificial activities and blessing activities, while the sacrifice and blessing requires the participation of the whole family members, which can increase the family cohesion. Finally, Shaman has the function of divination. Shaman can use divination to communicate with the gods in order to judge evil. Healing and exorcism is the most important function of Shaman, and Shaman is able to treat people's health through practice or the way of jumping.

\section{The Value of Olunchun Shaman Culture}

\section{A. Display Folk Customs}

The display of folk customs is one of the values of the Shaman culture of the Olunchun ethnic group. The Olunchun ethnic group of Shaman is relatively simple, and has a strong personality. They pay much attention to life and custom in their long life, and seldom pay attention to political utility. Their worship of god and god was built on the basis of life, for example,In order to gain more prey from the hunters, they offer sacrifices to the hunting gods before hunting. They formed a strong folk customs in the long life, and the Shaman culture embodies the folk customs of the Olunchun ethnic group.

\section{B. Display Regional Culture}

The display of regional culture is an important embodiment of the cultural value of the Olunchun ethnic group. In the long life, the people of Olunchun have established excellent national culture, and their cognitive level has been greatly improved. The emergence of various forms of art has greatly enriched the people's spiritual life, and the use of medical treatment has become a unique symbol of the Shaman of the Olunchun ethnic group. At the same time, the Shaman culture of the Olunchun ethnic group is an important part of China's cultural treasure, which is of great significance to the development and inheritance of national culture.

\section{The Olunchun Shaman CUltural ThOUght}

\section{A. The World View of Universe}

1) Creationism: Shamanism believed that the universe was not separated at the beginning of the earth. The whole universe was a chaotic world, and the gods created the world and the universe. Moreover, Shamanism believed that the universe was originally a matter of water, cloud, gas and other natural substances. The first gods, tengger, created people similar to himself according to his appearance. In Shamanism, god is the ruler of all things and the origin of all things.

2) Multilevel cosmology: Shamanism believes that the universe is a three-dimensional world, with the atmosphere, the middle and the lower, and each of them contains many layers. For example, the upper layer is divided into nine, 
seven or three layers. And Shaman deepens "god of god creation" to be gifted for the 17th floor, will be divided into nine layers. In some places, Shamanism divides the universe into nine days. The Shamanism of different places is different to the stratification of the universe, but the multilayer cosmology is affirmed, and the universe is stratified into multiple layers.

3) Shaman tree worship: Shaman believes that there is a cosmic tree between heaven and earth that connects the upper, middle and lower worlds. Shaman travels through the universe tree to The Three Kingdoms. The tree of the universe is also filled with Shaman trees, and different nationalities describe the shape, length and growth of the Shaman trees. In the process of sacrificial rites, the ritual of the pole worship is derived from the concept of Shaman trees. The worshippers choose to eat long dry and place sacrifices on the top to serve the gods in heaven.

\section{B. The Concept of the Soul}

Shamans believe that there are three souls, the Lord, the corpse or the soul. The main soul is the foundation of life. When the human life ends, the spirit will go away and become a wandering soul. The Shaman is far away from the site of the spirit of the soul and the spirit of the dead. The soul is very active and can leave the human body during sleep. Shamans believe that dreaming is the result of wandering soul. The soul of the corpse is the soul that guards the human body, some of the soul can regenerate. Therefore, in the age of hunting civilization, the tungusic people attached great importance to animal remains and believed that animal remains could be transformed into new animals, thus increasing the number of animals in nature.

\section{Polytheism}

There are many gods in Shamanism, and each of them is blessed by mankind. Therefore, Shamanism has many gods worship. Specifically, Shamanism is animal worship god, the Wolf, eagles, wild boar, bears, deer, birds, etc. As the object of worship, think that these animals can help people overcome evil, protect people's lives. In addition, Shamanism worships the plants very much, and has a special affection for the trees, such as willow, elm, birch, etc. In addition, Shamanism greatly adores the natural forces, and there is the worship of natural forces such as Mountain god, Wind god, Rain god and thor.

\section{The Role OF SHAMAN CUlture to OlunchuN PEOPLE}

\section{A. The Role of Survival}

In the era of poor medical treatment, Shaman occupied a very important position in the medical treatment of Olunchun. Specifically, Olunchun people's living conditions are bad, in the process of its survival to triumph over years, disease, and the harm of mosquito, and Shaman through unique medical thaumaturgy driven disease, provides a certain guarantee for Olunchun people's health. At the same time, before the harvest and hunting, Shaman will resort to the unique sacrificial ceremony, pray for the people of the nation, pray for the harvest and increase the prey.

\section{B. The Role of Production}

The Olunchun people did not pay attention to farming, and the hunting was the main way to survive. However, the living conditions of the people of Olunchun are worse, and the hunting places are full of dangers. Before hunting, Shaman would offer sacrifices to the gods, so that the Olunchun people would be able to hunt in designated places under Shaman's guidance to obtain more prey. And wise Shaman with astronomical astrology, geography, and animal behavior relevant life experience judgment prey species, such as position, to guide of Olunchun, in order to achieve the goal of satisfy national masses life.

\section{The Role of the Mind}

Shaman is an important carrier of the communication between the Olunchun and the god. In other words, it is the spokesman of god's message. Therefore, their speech and behavior have a strong influence. The influence of Shaman on the people of Olunchun is not only limited to life and production, but also penetrates deeply into its spiritual level. Shaman often displays its powerful ability by casting spells and offering sacrifices to the gods, so as to achieve the goal of conquering the national masses. They believed in harvest, make through sacrifice national masses through for the treatment of patients with witchcraft to eliminate or relieve patients' pain, even before the war through the sacrifice to the gods, give the army strong self-confidence.

\section{THE SIGNIFICANCE OF THE CULTURAL INHERITANCE OF OLUNCHUN SHAMAN}

\section{A. Carry forward the Excellent Culture of Minority Nationalities}

The cultural inheritance of Olunchun Shaman can carry forward its national excellent culture. It is very important to form the ethnic culture and customs and customs. At the same time, in the long period of Shaman inheritance, it has formed its unique national culture. In the process of integration development, every national culture collision and fusion of each other, learn from each other in order to better development between various nationalities other nation's excellent culture, and carries on the improvement to achieve the purpose of raise the nation's cultural influence. Therefore, the Shaman culture of Olunchun has promoted the development of minority culture to a certain extent, which is of great practical significance for carrying forward the fine minority culture.

\section{B. Promote the Development of National Cultural Industry and Regional Economy}

Shaman occupies a very important position in the Olunchun ethnic group, and also creates many cultural products. For example, Shaman needs to use a large number of sacrificial tools during the sacrificial ceremony to assist him to complete the sacrificial ceremony. Therefore, the 
sacrificial industry has been developing rapidly in the Olunchun people, which greatly promoted the development of local economy. In addition, at present, Mr \&matrimonial has become the ancient ancestors of the cultural traditions, many tourist attractions are around the Shaman and orogen culture as the carrier, visitors to the Olunchun ethnic tourism has greatly stimulated the development of the national cultural industry, but also promote the rapid improvement of level of regional economy.

\section{CONCLUSION}

It is necessary to trace the origin of oroqun shaman culture.To trace the origin of the problem can answer the question of the shaman culture belief of the oroqunchun nationality, Can understand the production and function of shaman,We can interpret the ideological connotation of oroqun shaman culture, We can understand the positive effect of shaman culture on oroqun people.By answering the above questions, We understand that the oroqun shaman culture has rich value.At the same time, oren chun shaman cultural heritage is also very meaningful.

\section{ACKNOWLEDGEMENT}

This paper is a research project of Heilongjiang provincial philosophy and social science research project, "Investigation and protection research on the preservation of the saman culture of Olunchun ethnic group in Heilongjiang province". Approval number: Research results of 16MZE01.

\section{REFERENCES}

[1] Song Lili, Lu Jingjing, Wu Hao. Research on the survival investigation and protection of Shaman culture in Olunchun, Heilongjiang province $[\mathrm{J}]$. Comparative study on cultural innovation, 2011,1(17):22-23.

[2] Zhang Yifan. On the integration of Shaman culture and the culture and art of Olunchun culture $[\mathrm{J}]$. Journal of Harbin Institute of Technology (social sciences edition),2001(04):101-104.

[3] Jiang Yuxi, Wang Weiwei. The current situation and analysis of the religious culture of the Olunchun ethnic group -- a case study of the national township of yinan in the great xing 'an mountains [J]. National BBS,2014(10):65-69. 